\title{
STABILITY COMPARISON OF TULASI (Ocimum tenuiflorum L.) LEAF GEL HAND SANITIZER USING 0.5\% AND 1\% CMC-Na
}

\author{
Dewa Ayu Made Adnya Swari ${ }^{*}$, Ni Putu Udayana $A^{2}$, Ni Made Dharma Shantini $\mathrm{S}^{2}$ \\ ${ }^{1}$ Clinical Pharmacy, International Bali University, Bali, Indonesia \\ ${ }^{2}$ Pharmacy, Mahasaraswati University, Bali, Indonesia \\ Corresponding author email: swariadnya@gmail.com
}

\begin{abstract}
Background: Hand sanitizers contain $62 \%$ alcohol, softener and moisturizer. High alcohol content is able to irritate and make hands dry. A suitable moisturizer is needed for this preparation. Objective: The aim of this study is to evaluate the physical quality of gel hand sanitizer formulation of Ocimum tenuiflorum with $\mathrm{CMC}-\mathrm{Na}$ as a gelling agent at a concentration of $0.5 \%$ and 1\% CMC-Na. Methods: Data were collected at week-0,1,2,3,4, and replication is performed three times at each concentration of each measurement. The test results of the spread and adhesion data analysis using SPSS with a 95\% confidence level. Results: Dispersive power and adhesion showed no significant difference $(p<0.05)$ at week 0 and week 4 means second-hand sanitizer gel formulation concentration is not stable. Gel hand sanitizer leaves of Tulasi (Ocimum tenuiflorum) at a concentration of $1 \% \mathrm{CMC}-\mathrm{Na}$ stable from week 0 to week 3 , while the concentration of $0.5 \%$ CMC-Na change at week 2 . Gel hand sanitizer leaves of Tulasi (Ocimum tenuiflorum) with a gelling agent CMC-Na should need to be titrated. Conclusion: Gel hand sanitizer leaves of Tulasi (Ocimum tenuiflorum) that use concentrations of $1 \% \mathrm{CMC}-\mathrm{Na}$ as a gelling agent have a physical quality that is more stable than the organoleptic test concentration of $0.5 \% \mathrm{CMC}-\mathrm{Na}$.
\end{abstract}

Keywords: Hand sanitizer, Ocimum tenuiflorum L., CMC-Na, Physical quality evaluation

\section{INTRODUCTION}

In maintaining the health of our bodies, maintaining hand hygiene is very important. In our daily activities, the hands are often contaminated with microbes, so the hands can be an intermediary for microbial entry into our bodies. One of the simplest and most common ways to maintain hand hygiene is to wash your hands using soap. Along with the increasing busyness of the community, especially in urban areas, and the number of instant products that are fast-paced and practical, the product appears to innovate waterless hand sanitizer known as antiseptic hand sanitizer or hand sanitizer. $^{[1]}$ The increasing desire of the community to use natural ingredients or "back to nature" is responded to by the number of topical products made from active plants for health care, cosmetics and disease prevention, one of which is hand gel sanitizer. ${ }^{[2]}$

In general, hand sanitizers contain $62 \%$ alcohol, softener and moisturizer. But alcohol is able to irritate and able to make hands dry. In addition, the use of chemical hand sanitizers has a considerable impact on health, which can increase the risk of viral infections that trigger inflammation of the digestive tract. Therefore, the use of natural ingredients can reduce the risk of the emergence of digestive disorders. ${ }^{[3]}$ 
Ocimum tenuiflorum Linn or Tulasi is one of the plants that has antibacterial properties. The main chemical ingredients present in $\mathrm{O}$. tenuiflorum are oleanolic acid, ursolic acid, rosmarinic acid, eugenol, carvacrol, Linalool, and $\beta$ caryophyllene. $^{[1]}$ Initial chemical tests performed on all extracts showed the presence of saponins, alkaloids, flavonoids, cardiac glycosides, steroids, phenols and tannins. ${ }^{[4]}$ Thus this tulasi leaf has the potential to be developed into antibacterial preparations, one of which is made in the form of gel preparations.

Gel formulation requires gelling agent compounds as gelling agents. Gelling agents of various types, including CMC$\mathrm{Na}$, Carbopol and Tragacanth. CMC-Na is a semi-synthetic polymer base gel. CMC$\mathrm{Na}$ has the best physical characteristics (organoleptic and viscosity) chosen to be used as the basis for hand antiseptic gel preparations. ${ }^{[5]} \quad$ Thus, researchers interested in making natural hand sanitizer formulations from tulasi leaves. The purpose of this study is to be able to evaluate the physical quality of the gel hand sanitizer from Ocimum tenuiflorum with $\mathrm{CMC}-\mathrm{Na}$ as a gelling agent at a concentration of $0.5 \% \mathrm{CMC}-\mathrm{Na}$ and $1 \%$ CMC-Na.

\section{MATERIALS AND METHODS}

The method used was experimental by direct observation of the gel hand sanitizer tulasi leaf infusion. This research was conducted in the laboratory.

\section{A. Materials}

The material used in this study was tulasi leaves (Ocimum tenuiflorum L.), fresh leaves were taken from Sibang Gede Village, Badung Regency, Bali was determined at LIPI. The chemicals used in this study were CMC-Na, Glycerin, Methylparaben, Propylene glycol.

\section{B. Procedure for making an infusion of tulasi leaves}

Twenty-five grams of tulasi leaves were added with $50 \mathrm{~mL}$ of water (more than $10 \%$ ), then heated with the water heater for 15 minutes until it reaches a temperature of $90^{\circ} \mathrm{C}$. Add enough hot water through the pulp to obtain the desired volume of infusion. How to make CMC-Na moistened with an infusion of tulasi leaves as much as 20 times the weight of CMC-Na then crushed. In the porcelain, cup nipagin is dissolved into glycerin, then added to the mortar. Then propylene glycol was added. All remaining infusion was added little by little and then stirred until a homogeneous gel is formed.

\section{Evaluation of Hand Sanitizer Gel}

1. Organoleptic observation

Organoleptic observation included physical appearance, colour and odour that were observed visually. The preparation was declared stable if the color, odour and appearance do not change visually during storage and were not overgrown with fungus. ${ }^{[6]}$

2. Homogenity Observation

Homogenity observation was carried by applying gel samples to a piece of glass or other suitable transparent material. The preparation must show a homogeneous arrangement, and no coarse grains were seen. ${ }^{[7]}$

3. $\mathrm{pH}$ Observation

The $\mathrm{pH}$ test of the preparation was carried out using universal $\mathrm{pH}$ sticks dipped in a diluted gel sample. After being completely immersed, the universal $\mathrm{pH}$ was seen to change in color and matched with universal $\mathrm{pH}$ standards. ${ }^{[8]}$

4. Scattering power measurement The spread test was carried out by means of a gel preparation weighed as much as 0.5 grams, after that the gel 


\section{产 JPSA}

was placed just under the square glass underneath accompanied by a diameter scale, then covered with other glass that had been weighed and left for one minute, after which the spread diameter was measured. After 1 minute, 50 grams of weight was added and left for 1 minute, and then the spread diameter was measured. The same thing is done every 1 minute with the addition of a load of 50 grams, and then the spread area is measured using the bar. ${ }^{[9]}$

5. Measurement of adhesion

The stickiness test is done by placing the preparations on the glass of the object which had been determined its width. The other object-glass was placed on the gel, pressed with a load of $1 \mathrm{~kg}$ for 5 minutes. Test kits were given a weight of 80 grams and then recorded the time of the release of the gel from the object glass. ${ }^{[8]}$

\section{RESULTS AND DISCUSSION}

The evaluation of the antibacterial gel of Ocimum tenuiflorum leaves with different concentrations was tested every week from 0,1 st, 2 nd, $3 \mathrm{rd}, 4 \mathrm{rd}$ week. Tests carried out include examination of appearance or organoleptic, homogenity test, an examination of the degree of acidity $(\mathrm{pH})$, an examination of spreadability and examination of adhesion. From the results of the organoleptic test, the preparation of hand sanitizer gel with a concentration of $0.5 \%$ experienced a change in viscosity, color and odor starting in the 2nd week. The hand sanitizer gel concentration of $1 \%$ experienced changes only in the 4th week. This can be caused by the storage of hand sanitizer gel preparations at room temperature that is not controlled or formulations that are not optimal.

After the organoleptic test, a $\mathrm{pH}$ test is then performed to determine the acidity of the preparation and to adjust the $\mathrm{pH}$ of the preparation to the $\mathrm{pH}$ at which the application is applied. The application place for the preparation of a gel hand sanitizer for infusion of tulasi leaves is a hand that is protected by a layer of skin. Skin $\mathrm{pH}$ ranges from 4-6. ${ }^{[9]}$ Based on the test results, it is known that the $\mathrm{pH}$ of the preparation of gel hand sanitizer and tulasi leaves with a concentration of $0.5 \%$ and $1 \%$ has a stable $\mathrm{pH}$ from week 0 to week 4 that is $\mathrm{pH}$ 5. This shows that these preparations still meet the skin $\mathrm{pH}$ requirements.

Furthermore, the test data on the spreadability and adhesion obtained from the measurement are continued by statistical data processing. Scattering and sticking test data were first tested using the Shapiro Wilk method to see the normality of the data. Shapiro Wilk test results obtained are the spreadability and adhesion of the test output with SPSS obtained $\mathrm{p}=$ 0.001 . Because of the value of $p<0.05$, it was concluded that the power distribution is not normal. Thus, the ANOVA test requirements were not fulfilled. Therefore a decision was made to use the alternative test, the Friedman test. Based on the results of the Friedman test on the spread and stickiness test at the two concentrations showed a significant difference $(p<0.05)$ at week 0 to week 4 . It can be concluded that the preparation of the second-hand sanitizer gel concentration was unstable.

Based on the $\mathrm{pH}$ test of the secondhand sanitizer gel, the concentration remained stable from week to week. However, based on the organoleptic test, the preparation of hand leaf gel sanitizer with tulasi leaf infusion with CMC-Na concentration of $1 \%$ was more stable until the 3 rd week than the preparation of hand leaf gel sanitizer with TEC leaf concentration with $0.5 \% \quad \mathrm{CMC}-\mathrm{Na}$ concentration. 
Table 1. Organoleptic observation results

\begin{tabular}{|c|c|c|c|c|c|c|}
\hline \multirow[b]{2}{*}{$\begin{array}{l}\text { Organoleptic } \\
\text { Observation }\end{array}$} & \multirow[b]{2}{*}{ Concentration } & \multicolumn{5}{|c|}{ Observation time } \\
\hline & & Week 0 & $1^{\text {st }}$ week & $2^{\text {nd }}$ week & $3^{\text {rd }}$ week & $4^{\text {th }}$ week \\
\hline \multirow{2}{*}{$\begin{array}{c}\text { Appearance } \\
\text { (Viscosity) }\end{array}$} & $0,5 \%$ & Thick & Thick & $\begin{array}{l}\text { Thick, } \\
\text { slightly } \\
\text { runny }\end{array}$ & Liquid & Very liquid \\
\hline & $1 \%$ & Thick & Thick & Thick & Thick & $\begin{array}{c}\text { Thick, slightly } \\
\text { runny }\end{array}$ \\
\hline \multirow[t]{2}{*}{ Color } & $0,5 \%$ & $\begin{array}{l}\text { Blackish } \\
\text { brown }\end{array}$ & $\begin{array}{l}\text { Blackish } \\
\text { brown }\end{array}$ & $\begin{array}{c}\text { Blackish } \\
\text { brown } \\
\text { a little } \\
\text { thick }\end{array}$ & $\begin{array}{c}\text { Blackish } \\
\text { brown } \\
\text { a little } \\
\text { thick }\end{array}$ & $\begin{array}{l}\text { Very dark } \\
\text { black brown }\end{array}$ \\
\hline & $1 \%$ & $\begin{array}{l}\text { Blackish } \\
\text { brown }\end{array}$ & $\begin{array}{c}\text { Blackish } \\
\text { brown }\end{array}$ & $\begin{array}{c}\text { Blackish } \\
\text { brown }\end{array}$ & $\begin{array}{c}\text { Blackish } \\
\text { brown }\end{array}$ & $\begin{array}{c}\text { Blackish } \\
\text { brown } \\
\text { a little thick }\end{array}$ \\
\hline \multirow{2}{*}{$\begin{array}{c}\text { Odor } \\
\text { (The Scent) }\end{array}$} & $0,5 \%$ & Tulasi leaf & $\begin{array}{l}\text { Tulasi } \\
\text { Leaves is a } \\
\text { little sharp }\end{array}$ & $\begin{array}{l}\text { Tulasi } \\
\text { Leaves is } \\
\text { sharp }\end{array}$ & $\begin{array}{c}\text { Tulasi } \\
\text { Leaves is } \\
\text { sharp }\end{array}$ & $\begin{array}{l}\text { Tulasi Leaves } \\
\text { is very sharp }\end{array}$ \\
\hline & $1 \%$ & Tulasi leaf & Tulasi leaf & Tulasi leaf & Tulasi leaf & $\begin{array}{l}\text { Tulasi Leaves } \\
\text { is a little sharp }\end{array}$ \\
\hline
\end{tabular}

Table 2. homogenity observation results

\begin{tabular}{|c|c|c|c|c|c|}
\hline \multirow{2}{*}{ Concentration } & \multicolumn{5}{|c|}{ Observation time } \\
\cline { 2 - 6 } & Week 0 & $\mathbf{1}^{\text {st }}$ week & $\mathbf{2}^{\text {nd }} \mathbf{w e e k}$ & $\mathbf{3}^{\text {rd }} \mathbf{w e k}$ & $\mathbf{4}^{\text {th }} \mathbf{w e e k}$ \\
\hline $0,5 \%$ & Homogen & Homogen & Homogen & Homogen & Homogen \\
\hline $1 \%$ & Homogen & Homogen & Homogen & Homogen & Homogen \\
\hline
\end{tabular}

Table 3. Results of pH measurements

\begin{tabular}{|c|c|c|c|c|c|}
\hline \multirow{2}{*}{ Concentration } & \multicolumn{5}{|c|}{ Observation time } \\
\cline { 2 - 6 } & Week 0 & $\mathbf{1}^{\text {st }}$ week & $\mathbf{2}^{\text {nd }} \mathbf{w e e k}$ & $\mathbf{3}^{\text {rd }} \mathbf{w e e k}$ & $\mathbf{4}^{\text {th }}$ week \\
\hline $0,5 \%$ & 5 & 5 & 5 & 5 & 5 \\
\hline $1 \%$ & 5 & 5 & 5 & 5 & 5 \\
\hline
\end{tabular}

Table 4. Results of measurement of dispersion

\begin{tabular}{|c|c|c|c|c|c|c|}
\hline \multirow{2}{*}{ Load used (grams) } & \multirow{2}{*}{ Concentration } & \multicolumn{5}{|c|}{ Spread diameter (cm) } \\
\cline { 3 - 7 } & Week 0 & $\mathbf{1}^{\text {st }}$ week & $\mathbf{2}^{\text {nd }}$ week & $\mathbf{3}^{\text {rd }}$ week & $\mathbf{4}^{\text {th }}$ week \\
\hline $\begin{array}{c}\text { The weight of the glass }= \\
\text { 46 gram }\end{array}$ & $0,5 \%$ & 11 & 11.5 & 10 & 11.37 & 10 \\
\hline $\begin{array}{c}\text { B The weight of the glass } \\
=46 \text { gram }\end{array}$ & $1 \%$ & 7 & 6.5 & 7.25 & 8.75 & 9.42 \\
\hline $46 \mathrm{gr}+50 \mathrm{gr}$ & $0,5 \%$ & 12 & 12 & 11 & 12 & 12 \\
\hline $46 \mathrm{gr}+50 \mathrm{gr}$ & $1 \%$ & 8.25 & 8.75 & 8.25 & 10 & 10.75 \\
\hline $46 \mathrm{gr}+100 \mathrm{gr}$ & $0,5 \%$ & 12 & 12 & 12 & 12 & 12 \\
\hline $46 \mathrm{gr}+100 \mathrm{gr}$ & $1 \%$ & 8.75 & 9.25 & 8.5 & 11.12 & 12 \\
\hline
\end{tabular}

Table 5. Results of adhesion measurements

\begin{tabular}{|c|c|c|c|c|c|}
\hline \multirow{2}{*}{ Concentration } & \multicolumn{5}{|c|}{ Adhesion time (seconds) } \\
\cline { 2 - 6 } & Week 0 & $\mathbf{1}^{\text {st }}$ week & $\mathbf{2}^{\text {nd }} \mathbf{w e e k}$ & $\mathbf{3}^{\text {rd }} \mathbf{w e e k}$ & $\mathbf{4}^{\text {th }}$ week \\
\hline $0,5 \%$ & 1 & 1 & 0.77 & 0.63 & 0.63 \\
\hline $1 \%$ & 1 & 1 & 0.9 & 0.8 & 0.73 \\
\hline
\end{tabular}




\section{CONCLUSION}

Based on these results, it can be concluded that the gel hand sanitizer of tulasi leaves (Ocimum tenuiflorum), which uses a $1 \%$ CMC-Na concentration as a physical gelling agent has more stable stability than a CMC-Na concentration of $0.5 \%$.

\section{CONFLICT OF INTEREST}

This paper was written independently. All authors disclose no financial or personal relationships with other people or organizations that could inappropriately influence the work.

\section{ACKNOWLEDGEMENT}

We thank to lecturers and staff in department of Pharmacy, Universitas Bali Internasional and Pharmacy, Mahasaraswati University, Bali, Indonesia for the support in the implementation of research.

\section{REFERENCES}

1. Desiyanto, Fajar Adi, Djannah, Sitti Nur. The Effectiveness of Handwashing Using Antiseptic Hand Sanitizer Liquid on the Amount of Germs, Yogyakarta: Ahmad Dahlan University; 2013.

2. Retno Sari and Dewi Isadiartuti. Study on the Effectiveness of Hand Antiseptic Gel Preparations; 2006

3. Maswadeh, H., Semreen, M., Naddaf, A. Anti-infalammatory Activity of Achillea and Ruscus Topical Gel On Carrageenan-induced Paw Edema in Rats. Acta Poloniae PharmaceuticaDrug Research. 2006; 63 (4): 277-280.

4. Dhal, Yogamaya. Evaluation of Antioxidant Activity of Ocimum Tenuiflorum L., An Important Medical Herb, India: IJPAES; 2012.

5. Khaerunisa, Riana. Formulation and Effectiveness Test of Hand Antiseptic Gel Preparations Containing Ethanol Extract of Arumanis Mango Leaves
(Mangifera indica L.), UNISBA; 2015.

6. Roudhantini. Test the Effectiveness of Anti Acne Gel Essential Oil Preparation of Sambal Orange Leaves (X Citrofortunella microcarpa (Bunge) Wijnands) Against Propionibacterium Acne and Staphylococus Epidermidis. UNTAN; 2015.

7. Director General of POM RI. Pharmacopoeia Indonesia Edition IV. Jakarta: Ministry of Health of the Republic of Indonesia; 1995.

8. Suardi, M., Armenia, Anita, M. Clinical Formulation and Benzoil Peroxide-Acne Gel Clinic Test. Journal of Science and Technology. 2008; 3(1) : 70 -76.

9. Sandhu, P., Ajay, B., Snuil, K., Bhawana, K., Shail, K., Davashih, R., et al. Additives in Topical Dosages Forms. IJPCBS. 2012; 2(1) : 78 -96. 